\title{
Fear Factor Caused by Outside Propaganda Pressure and its Influence on the Policy of the Small Countries
}

\author{
Maia Urushadze \\ Ph.D. Researcher of Political Science, \\ Caucasus International University
}

\begin{abstract}
According to political theorists, propaganda can have the most powerful influence through activating the fear factor. Therefore, it is very important to identify the influence on the political decision-making process made by propaganda directly, or indirectly, through activation of the fear factor.

Due to the nature of the fears (they might be rational or irrational) caused by propaganda, they can lead to social turmoil. Thus, we link outside propaganda influence to the security of the state, including small states that do not have the resources to pursue their own interests and therefore become a policy object for large actors.

We investigate outside propaganda pressure in small countries and its impact on the policy internal affairs, or international relations. In this regard, we studied open and covert propaganda of major actors and the frequent appeals of their narratives to the fear factor as a tool of achieving short-term goals at the expense of the same time harming long-term goals. We investigated narratives of target countries' political spectrum (as internal as well as external actors) which amplify the fear factor (intentionally or unintentionally). We studied the nature of these narratives and the forms of societies' responses to them.

The article is based on the results of an in-depth case study in Georgia and a comparison of the results of other post-communist (post-Soviet and central European) case studies. In the case of Georgia, we identified harmful and useful narratives for the long-term strategic development of the country. This enabled us to identify pressure that might negatively impact the national security of the country.

Nowadays, at the background of the development of contemporary communication technologies and highly effective focus of communication channels that can be made on the audience, when we face the transformation of information warfare methods, political communication is necessarily multifaceted and the relevant campaigns do contain elements of psychological warfare.

That is, communication texts of political entities mostly contain messages that comprise a component of information warfare and affect the mental health of society.
\end{abstract}

Keywords: propaganda; political communication; security; media; politics. 


\section{Introduction}

In 2018, according to the Freedom House report ${ }^{\mathrm{i}}$, Georgia's democracy score had been decreased. The report reads that Georgian authorities had found it difficult to 'strike a balance between the contradictory goals of advancing democratization on the one hand and consolidating power on the other'. At that time, the decrease of democracy score coincided with strengthening Russian propaganda in Georgia.

In 2021, according to Freedom House Report 2021 ${ }^{\text {ii }}$, the democracy score of Georgia decreased again. There report mentioned that 'In Georgia, the opposition's boycott of 2020 parliamentary elections and the February 2021 arrest of opposition leader Nika Melia clearly demonstrated the end of the country's recent reform attempts. Georgia's democracy score is now close to where it was a decade ago, before the current ruling party rode to power on a wave of public frustration with the increasingly autocratic incumbents. ${ }^{\text {,ii }}$ In this case, the decrease of democracy score coincided with predictable effects of strengthening of the Russian propaganda in previous years.

Therefore, we face the situation where propaganda pressure from outside of the country has had its impact through the following chain: the opinions of individuals (in some cases related to the Russian Soft Power) were transferred to the narratives of representatives of different public small groups and turned into the political discourse.

\section{Nature of the Russian propaganda}

The last decade's discourses about Russian propaganda showed the need for evaluation of strategic communication that has been carried out by the Kremlin after the breakdown of the USSR. This communication still goes through the network of USSR-experience-based soft power tools. These tools include connections with political actors, businessmen, NGOs, and large media networks, that provide propaganda support to the Russian messages.

At the end of the last century, the Kremlin's activity was identifiable in post-Soviet countries, at the beginning of the 21st century - in Central European, Asian and African states, and afterward - Western Europe and the United States. The officials of the Russian Federation consider these activities as necessary instruments to protect national interests, but the US and EU administrations view them as a threat. As a result, strategic communication of the main international agenda makers is being conducted in the background of an active confrontation of interpretations. This confrontation creates favorable conditions for giving incentive to internal confrontation in other countries' societies.

In 2017 CENAA $^{\text {iv }}$ studied cases of information warfare in Europe. Report 'Information Warfare as a Geopolitical Tool' mentioned that: 'Russia is able to use democracy against democracies and the freedom of information to inject disinformation into various target groups under the label of freedom of speech. Information warfare blurs the border between peace and war and between fact and fiction.' The present situation is even more acute.

\section{Nature of the Hybrid Warfare}

Hybrid warfare according to Frank Hoffman is 'the combination of the multiple types of warfare used simultaneously to flexibly fit the political goals in particular circumstances'v. According to political theorists, hybrid warfare is composed of 4 main parts: information warfare, psychological operations, use of special forces, and cyber operations. They also note $^{\text {vi,vii,viii }}$ that propaganda has the most powerful influence on the target country through activating the fear factor. In contrast to the soft power background functioning, the main task of which is to attract, co-opt and persuade, powerful propaganda attacks are characterized by 


\section{SOCIAL SCIENCES IN THE 21ST CENTURY}

accelerating fear factor in the consciousness of the target countries' societies. The recent activities of the Russian Federation show, that nowadays it is not necessary to conduct a fullscale information war. It is enough to implant the hidden fear in the consciousness of the target country through aggressive strategic communication and support its permanent presence in the background mode via soft power instruments.

\section{Research Structure}

Our objectives were:

a) To study specifics of strategic communication of external and local political actors and their narratives by the countries. This enabled us to acquire information to compare:

- narratives that implant irrational fears in the public consciousness;

- narratives that weaken this fear;

- narratives that are neutral to the fear factor.

b) To compare all political actors' narratives and evaluate the general rhetoric and its intersection with external propaganda.

c) To analyze the narratives of political actors in terms of national security and distinguish harmful and useful narratives for the long-term strategic development of the target country.

d) To detect examples of the influence on the public, which are exposed to these narratives, measure the influence of different political actors on the society and, consequently, on the political decision-making process in the country.

We used the traditional theoretical base of political communication study - the agenda-setting ${ }^{\text {ix }}$ and framing ${ }^{\mathrm{x}}$ theories.

To collect the necessary data for the survey, we studied open sources, previous research works, and focus groups in target countries. We selected three focus groups, first of them composed of the leaders of political actors (speakers, board members, etc.), second - representatives of other actors (NGOs', business, culture, and sports representatives), and third - ordinary citizens. The third focus group members' quantity was equal to the total amount of first and second focus groups. This enabled us to use the methods of proportional, bivariable, and multivariable analysis at the final stage of our research.

The first focus group was selected:

a) according to results of quantitative analysis of their reference index in electronic media over the past 10 years;

b) according to local media evaluations;

c) according to their ratings during the last two elections.

As a result, with the formation of focus groups, we collected the necessary variables for the data analysis stage - the number of powerful political actors by country (for example Georgia - 5, Poland - 3, Romania - 3, etc.).

The second group was selected according to the criteria of high visibility in the local media agenda.

For the third focus group, which constitutes ordinary citizens, we used a random selection method in all countries.

At the end of this stage, we had a general political picture of the target countries, with powerful political actors of these countries and other actors in the local agenda.

After that, we collected data using the following methods:

a) Survey (preparation of questionnaire, structured personalized, telephone or written interviews via social networks);

b) Qualitative research (evaluations from media, other political actors, and 3rd focus group). 
To analyze the narratives of the actors we used qualitative research, frame-analysis, and content-analysis of their strategic agenda. Using the content analysis, we determined masked objectives in their communication texts, and frame-analysis (qualitative, comparative, and content analysis) helped us to determine the fear-factor-oriented narratives in their propaganda. To analyze how the political actors' strategical agenda comply with the agenda of media and society, a comparative analysis of the agendas of media, society, and political actors was required.

To analyze the efficiency of propaganda - on the one hand, we used the target audience summary of media-involved-in-the-campaigns, and on the other hand - in-depth interview of the 3rd focus group. Comparative analysis of the obtained results enabled us to determine the error rate of the research.

And finally, we conducted secondary data analysis. We measured an alleged error of the survey; found a correlation between positive, negative, and neutral narratives in relation to fear factor, and performed the bivariable and multivariable analysis of results).

\section{Fear Factor and Security}

Today, as the international agenda is filled with the wrestling of interpretations of powerful political actors, the information space is saturated with mutually exclusive narratives circulated by these actors that directly influence the moods of individuals and contribute to the polarization of society. A large part of these narratives is directly aimed at arousing rational and irrational fears in the societies of nation-states. Naturally, these fears are reflected in the domestic media of these countries - they are also replicated by the media and political actors. Ultimately, these fears affect both public sentiment and the political decision-making process. In this situation, it is especially important to understand how all this affects the security of small states.

First of all, it is necessary to determine who these external forces are, what interests you have in relation to the target country in general and what opportunities they have to achieve their goals. For this, first of all, the interests of 5 types of actors should be considered: the interests of global and regional actors, the interests of the neighborhood, the interests of actors whose diasporas are numerous in the country and those centers of international influence, who has a wide spectrum of interests and, therefore, gaining influence in the state/region may become an intermediate task for them.

It must be said that various powerful research institutes around the world are trying to measure the capabilities of soft power operating in the international arena today. The actors with their soft power are assessed on a number of criteria, among which economic and cultural influences come first. This is because we say that when the third leading component - information pressure (or propaganda) is highly activated, we are dealing with a hybrid war, an asymmetric threat, and a hard power, not a soft power.

\section{Measuring "Weight" of Propaganda}

The propaganda aimed at the external audience is present in the strategic communication of any country. However, different types of states face different challenges and, consequently, their propaganda matrices are also different. That's why the other frame which allows us to measure propaganda "weight" is a complex evaluation of the outside actors, including their interests, capabilities, and military potential.

According to our proposed rankings, the propaganda pressure is the lowest from the countries with a low level of social /economic development and falls only on the internal audience of the state. Propaganda narratives in this case are aimed at causing public satisfaction (or, in the case of opposition, dissatisfaction) with the acting government and maintaining state unity - 
replicating common national, universal, common threat, common welfare, or other unifying ideas in society. Naturally, the share of propaganda of this category of states in the international agenda is practically invisible.

However, neighboring countries also have external (neighborhood audience-oriented) propaganda. It does not matter what the relationship is with the neighbors at the moment. The task of regional leadership, established boundaries, increasing influence, and weakening foreign influence is conceptually always on the state security agenda and, even in a passive mode, is constantly monitored. Consequently, the share of this kind of propaganda in the modern global media space is very limited, since it reaches only the nearest neighborhood.

In the third category, relatively strong states, which are in the area of interest of regional and/or global leaders, another important component is added to the external and domestic propaganda matrices - the correct understanding of global security systems and the propaganda of selected systems. In other words, the government must justify its decision to enter into an alliance with this or that powerful political actor or group of actors. The share of propaganda flows of this category of states in the modern global media space is identifiable and, consequently, has some influence. However, it should be noted that this influence does not extend to regional scale and usually strengthens or weakens the propaganda of regional leaders and/or centers of global gravity.

The propaganda matrix for the fourth category, that is, for regional leaders, becomes even more complicated since the essence of regional leadership itself is reflected in the fact that the state has the ambition to be the rule-maker in the region itself. Consequently, narratives already appear in its matrix, which indicates its state, economic, institutional strength, success, and, if necessary, the possible threats posed by it to the adversaries. Propaganda flows in this category of states are easily identifiable, powerful, and influential. However, like the third category, their narratives typically weaken or reinforce the narratives of centers of global gravity.

Finally, the fifth category - centers of global gravity. According to our ranking, these are the political actors which themselves are the global "rulers of the game" and, therefore, they dictate the main directions of international security. This means that their propaganda matrix is focused on the propaganda of these directions and, along with all the above-mentioned propaganda directions, on the justification of the superiority of their own systems of international security.

In the case of Georgia, we face a struggle of interpretations between only two real influencers - the US and the Russian Federation - as the centers of such gravity of global and regional politics. Of course, this is also conditional, because, at a superficial glance, the factor of the third player - China, as well as the considerable force - the European Union, is not given proper consideration. However, it should be noted that in the current reality for China and the European Union, the propaganda flows of the United States and the Russian Federation and the "frame wrestling" that occurs between these flows are perceived as a threat. This is openly discussed in the $\mathrm{EU}^{1}$, and the Chinese government, in order to diminish the influence of the

\footnotetext{
${ }^{1}$ European Parliament resolution of 23 November 2016 on EU strategic communication to counteract propaganda against it by third parties (2016/2030(INI)) -

http://www.europarl.europa.eu/doceo/document/TA-8-2016-0441 EN.pdf
} 
external propaganda pressures and controls the international news media pursues a rather strict domestic policy $^{2}$ and has imposed strict censorship on the Internet. ${ }^{3}$

\section{Examples of action-oriented propaganda}

An example of action-oriented propaganda is an experiment conducted by the United States in 1938 for a domestic audience, when a humorous program was broadcast live on CBS, realistically covering the "chronicle" of the alleged alien invasion on Earth. The show caused a great deal of panic among the population, which was so severe that even led to casualties.

Despite the above-mentioned negative experience in history, the Norwegian public was also ready to believe such information in 2018, when the US space agency (NASA) conducted an experiment for scientific research (Auroral Zone Upwelling Rocket Experiment to study the flow of particles in the ionosphere) which was linked to an alien invasion and caused panic. ${ }^{4}$ The Kremlin's coordinated actions and rhetoric, which are gradually pushing the borders by shifting from the "zone of responsibility" to the depth of the territory of Georgia (so-called creeping annexation), aims at causing fear in Georgia. It instigates separatists or at least turns a blind eye to abductions of peaceful Georgian citizens.

The fear factor was the main trigger that led to the Caribbean crisis in the early 1960s and put the world at risk of World War III.

The Kremlin also manipulated by fear when it launched a targeted campaign in the Balkans and encouraged same-faith Serbs to fight a civil war against separatists despite the fact that the opposition on the part of the civilized international community.

It shall be noted here that Western support for Kosovar separatists at the end of the $20^{\text {th }}$ century led to increased Russian Federation support for separatism in the South Caucasus, namely, Georgia that resulted in a decrease in the pace of distancing of Georgia from the Russian Federation.

The most visible examples of the destructive influence of long-term propaganda are the largescale controversies in the history of mankind on religious grounds, which, unfortunately, continue up to the present day. Initial oral or subsequent written interpretations of one religion or another do not often call upon reconciliation with other religions, although theologians consider that the original religious texts did not contain such references. For example, Halil Muhammad $^{5}$, a professor of religion at the University of San Diego, writes that „Jihad and its derivative forms, as used in the Qur'an, mean to exert oneself, whether physically or intellectually, as an individual or part of a group, to promote a cause and earn the pleasure of God. The word was used in the Qur'an long before Muslims were permitted religiously to fight against their enemies. As such, its meaning does not necessarily refer to war, since striving in the path of God can be done by peaceful means." ${ }^{\text {"xi }}$

\footnotetext{
2 "China employs two million microblog monitors state media say". BBC News. 4 October 2013.

3 "Chinese Laws and Regulations Regarding Internet". Chinaeclaw.com. Archived from the original on 20 February 2012.
}

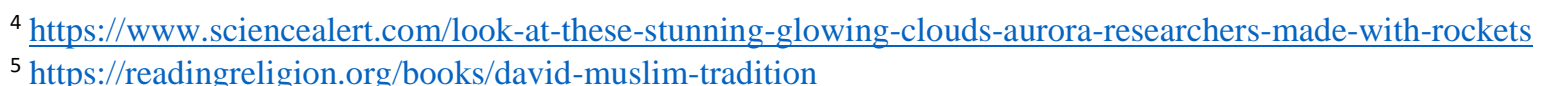




\section{Identified Trends}

As a result of the research, we have identified the following trends:

Strong regional and global actors are always trying to instill and arouse high esteem, and affection towards them in other countries.

The struggle for the leadership of powerful actors is accompanied by an emphasis on their own military strength.

While the narratives of powerful actors are not addressed directly at them, small countries are sensitive to these narratives of powerful global and regional actors - they are influenced by the aggressive rhetoric of powerful actors and exacerbate a sense of total danger.

In this situation, in addition to rational fear, irrational fears are rooted in society, the arousal of which in some cases may be favorable for one foreign state or a particular group of foreign states.

An example of this is the irrational fear of Georgian society towards Western culture, which seems to be causing "substantial change", "deprivation of culture and values" and thousand of other misfortunes. Fear of Turkey, which seems to be "swallowing us" and, naturally, fear of Russia, which "will roll over us by tanks if we do not behave properly."

Of course, strong political actors have their own interests and goals, so in some cases the threat is real, but giving it more importance poses a number of challenges to a small state, the most important of which are excessive defense spending, the disintegration of society (division into camps) and nihilism ("nobody is interested in our opinion, so we are not able to change something").

Powerful political actors influence small countries through propaganda narratives delivered through their own strategic communications.

The impact of this communication is permanent because the propaganda flows in a continuous mode, transformed into different narratives. However, narratives favorable to different global actors may be identical in content. Consequently, narratives from different sources may have a mutually reinforcing effect.

Major political actors, in their interests, at a time convenient to them and under the conditions they deem favorable, are stepping up propaganda pressure.

In this process, they activate not only diplomatic channels, but also soft power, which may not be perceived at all by small countries as an entity associated/affiliated with an external force. According to "game theory", in a particular game, on a particular field, the player who has a better chance of calculating the next moves based on the complete information about his opponent's resources, tactics, and strategies, has a better chance of winning. In the politics of small countries, in the process of realizing their interests, those external players who can control these further steps of opponents have a strategic advantage.

Controlling the actions of opponents is the simplest and most effective way to activate the fear factor in society, including irrational fears.

Opponents' actions can be managed most easily and effectively by activating the fear factor in society - including irrational fears.

\section{Fighting Harmful Propaganda influence in Georgia}

Several useful resources have been created in Georgia with the support of international donors to neutralize harmful propaganda. 


\section{SOCIAL SCIENCES IN THE 21ST CENTURY}

The FactChecker ${ }^{6}$ works toward measuring the factual accuracy of the public statements of politicians and other public figures. In addition, FactCheck aims to verify fake news being disseminated in social networks/media outlets and provide the public with true and correct information.

The MythDetector ${ }^{7}$ launched by the Georgian Media Development Foundation (MDF) works to uncover the truth behind the lies, explore hidden agendas, raise the level of media literacy and inform both people and institutions of Georgia about the impacts of disinformation.

MediaCritics ${ }^{8}$ created by Regulatory authority of broadcasting and electronic communications field - involves analyzing and evaluating media products to improve the quality of the media. The purpose of media criticism is to provide the public with professional and qualified analysis, to promote a critical perception of information, and, ultimately, to make informed and informed choices.

Despite this, it is necessary to realize that not only fake news harm our societies. Of course, there is undoubtedly the particular harmfulness of lies and fake news due to the propaganda interests. But it is also necessary to protect our societies from the irrational fears caused by external propaganda.

Today, the official StratCom frame in the Georgian media space is strong enough to nullify the dominance of ideas that are beneficial to the opposition camp in society.

As both the opposition bloc and the ruling party position themselves as pro-Western forces, the media struggle between their media outlets is not about popularizing a particular ideology, but about gaining the status of a major pro-Western force, often turning discourse into a personal confrontation. An example is the mutual accusations of the ruling and opposition camps about the "supporting Russian interests" by opponents, which is a classic case of creating an image of the enemy for propaganda purposes and then successfully using standard propaganda technologies, including the fear factor (In this case - fear of Russia as an aggressor).

\section{Recommendations}

In this situation, the following is important:

First of all, raising the political maturity of the society, increasing its resistance to external propaganda, which should be done by improving the education system, should be considered as a key issue for ensuring national security.

The second factor is the necessity to coordinate the strategic communication of state organizations. In fairness, it should be noted that from 2013 to 2019, the number of employees and remuneration of public employees in public relations departments in Georgia was constantly increasing. But, the second question is how coordinated their work has become. This question raises doubts, even given the results of a study of public attitudes and types of behavior today.

And third, also particularly important. Since external forces are looking for the weak niches in the governance of our states, the critique of which will allow their narratives to gain popularity in society and establish the desired image of these forces, it is important to preliminarily detect these niches and fill these niches to the maximum.

In the case of Georgia, based on the information presented in our study, which we have discussed here, it can be said that one of these niches - timely analysis of minority needs, quick response to their problems and their correct and timely information, delivery of information to

\footnotetext{
${ }^{6}$ https://factcheck.ge/en - an innovative media project in Georgia, implemented by Georgia's Reforms Associates and modelled on international analogues (www.politfact.com, www.factcheck.org).

${ }^{7}$ http://www.mythdetector.ge/ka -

8 https://mediacritic.ge/
} 
a wide range of forms and methods. However, this is not enough. In the case of Georgia, it is already at this stage necessary to raise the civic awareness of national minorities to the point where they are fully aware of their role in shaping the state security system in Georgia. The main thing here is their perception of their own security guarantees in the context of the security of the country.

This perception is of particular importance given that a large proportion of ethnic minorities in Georgia are ethnic Azerbaijanians and Armenians. In the Georgian media, there are frequent isolated cases of support for the policies of the neighboring countries in favor of the other neighbor from these ethnic minorities. This process was particularly notable in SeptemberOctober 2020, during the period of aggravation of relations between Azerbaijan and Armenia due to Karabakh. Social networks and media resources working on ethnic minority issues, in particular cases, directly replicated both the official narratives and propaganda manipulation information of neighboring states during their military confrontation. So-called "trolls" disguised as representatives of the opposing camp. They sought the emotional involvement of ethnic minorities living in Georgia in the conflict. If we take into account the geopolitical position of the country and the fact that today an economic transit corridor of international importance passes through Georgia, with Azerbaijan at one end of this corridor (at the same time, the issue of considering border issues is periodically raised in the political and media agenda of Georgia), and Turkey with ambitions to lead the region at the other end, it becomes clear that inspiring social turmoil in areas densely populated by ethnic Azerbaijanians is a direct challenge to the security of the country.

The second such niche is the condition of veterans who do not feel respected and valued by the state. Presumably, this is what forces many of them to get attracted by soft force. The same cannot be said of post-socialist Poland and Romania. Unlike Georgia, these countries have managed to value and ensure their veterans in a way that they no longer face such a problem. If nothing else, it seems that it is well understood here at the state level that in addition to avoiding external threats, veterans should be a particularly respected community as these are people whose example shall inspire young soldiers and further arouse the desire to defend the homeland. We have talked about this before. ${ }^{\text {iii }}$

\section{An additional Example of Harmful Propaganda in Action: Georgia and Covid-pandemic case, fear of virus and vaccine, political use of these fears.}

Our research was still going on when the Covid-19 pandemic started and the international media space was filled with a new struggle of interpretation, which was directly dictated by the fear factor: in one case - the fear towards the virus, and in the other - towards the vaccine. Thus, the case turned out to be interesting for us and provided an additional example to our research. The point is that the international outcry over the regulation of COVID-19 in many countries, including those which are Christian, and has received a radically negative response especially in the religious circles of society. The anti-vaccine sentiment was high on the agenda of the media, linking anti-pandemic measures to the "Second coming", universal control, and the "Seal of the Antichrist". As a result, anti-vaccine sentiments in some cases on a conscious and in some cases on a subconscious level coincided with the theory of anti-religious conspiracy, and as a result, both - conspiracy beliefs and antivaccine attitudes significantly strengthened. In a situation where controversies were substantial even in scientific medical circles, the coronavirus vaccine became unacceptable to a deeply religious section of the public, which resulted in a reduction of the speed of the vaccination process. 
Two different cases have been considered: countries in which sufficient numbers of the vaccine became available to the public immediately upon its development, and countries that failed to supply the vaccines to the population.

In the first case, anti-vaccine sentiments played a negative role both in terms of fighting the pandemic and in terms of the effectiveness of governmental agencies. Regulations have been prolonged over time, the growth rate of the economy has slowed down, and negative public opinion toward government has increased.

In the second case, anti-vaccination sentiments slowed down the rate of vaccination because the number of volunteers was small but the effectiveness of the governing bodies was less affected (the phrase "supplies are enough to continue vaccination at the current rate" speaks for itself).

Interestingly, in the middle strata of Georgian society, against the background of the closeness of societal values to Christian views, the psychological association of the act of vaccination took place with "receiving the seal of the Antichrist" not with "salvation", which would also be natural. Of course, this link was facilitated by anti-vaccine content obtained from Russian (and not only) sources, according to which vaccination was directly related to conspiracy theories. In the early stages of the pandemic, in April 2020, 62 out of 100 people surveyed in Georgia by random sampling were convinced that the virus was "artificially created", 11 said it "naturally evolved" and 27 said "I do not know - I do not have enough reliable information. " Approximately the same ratio was expressed openly in Georgian-language social networks. In a survey conducted in April 2020, 25\% of respondents were in favor of vaccination, 46\% opposed it while $29 \%$ answered that "I will observe and then decide."

However, in April 2021, the situation changed and only 44 out of 100 citizens surveyed by random sampling were convinced that the virus was artificially created. The percentage has almost been equally distributed among the proponents of "naturally evolving" (35) and between those who were unsure, who replied: "I do not know - I do not have enough reliable information" (21). Attitudes towards vaccination have also changed by 2021 - vaccination was preferred by $71 \%$ of respondents (including a - already vaccinated, b - those who have already booked themselves, or booked the first available vaccine for elderly parents, $\mathrm{c}$ - those who have been waiting for when a vaccine is made available to relevant age group; $d$ - those who planned to travel abroad and preferred to have the appropriate document at hand.); For $21 \%$, vaccination was perceived as an act of violence by the state (including those who were unsure of the reliability of the vaccines authorized by the WHO, who planned to avoid vaccination, and B categorically opposed to vaccination); $18 \%$ of the respondents had not yet formed and preferred to observe the processes.

It is noteworthy that in a survey conducted in April 2020, we did not ask additional questions to those who answered that "the virus does not exist at all and the agitation is artificially triggered by certain circles to achieve their goals" - just note that this answer was given by 52 people before we collect the desired number of respondents we interviewed. Since the rate turned out to be very high, we have already started the survey in 2021 with the question: "Does a coronavirus exist?" And we continued the survey only in case of a positive answer. Opposite to April 2020, only 22 respondents denied the existence of the virus, 12 were convinced that "the coronavirus is the common flu, just a frenzy for vaccine manufacturers to sell only pharmaceutical products," 6 believed that the problem was invented in favor of globalization, to tighten public governance, 1 said: "No, it is a special operation that China has planned and carried out against the world," while 3 said that "it is a special operation that the United States has planned and carried out to reduce China's influence and economic growth." 


\section{SOCIAL SCIENCES IN THE 21ST CENTURY}

Instead, the camp of supporters of the artificial origin of the virus has become much more radical and aggressive. Apparently, this camp was left out of the contingent that had previously been misled due to the lack of information, leaving only the part that uses only sources of controversial attitude towards Western culture (in the case of Georgia, most of such content flows from the Russian websites) as a source of information and directly links the vaccination process to conspiracy theories. In addition to activism against vaccination on open sources and social networks, this contingent has seen open protests against vaccination policies, calls for disobedience to anti-pandemic regulations, and attempts at public mobilization. Naturally, through this group, we faced the indirect negative impact of external propaganda on the strategic management and security of the state.

Conclusion: Nowadays, at the background of the development of contemporary communication technologies and highly effective focus of communication channels that can be made on the audience, when we face the transformation of information warfare methods, political communication is necessarily multifaceted and the campaigns produced within it do contain elements of psychological warfare. That is, the communication texts of political entities mostly contain messages that comprise a component of information warfare and affect the mental health of society.

P.S. Our research (PHDF-18-280) has been supported by the Shota Rustaveli National Science Foundation of Georgia (SRNSFG).

\section{References:}

i Freedom House Report, (2018). - https://freedomhouse.org/report/nationstransit/2018/georgia

ii Freedom House Report, (2020). - https://freedomhouse.org/report/nationstransit/2021/antidemocratic-turn

iii Zselyke Csaky, 2021, The Antidemocratic Turn, Freedom House Bulletin https://freedomhouse.org/sites/default/files/2021-04/NIT_2021_final_042321.pdf

iv CENAA, (2017). Information Warfare as a Geopolitical Tool http://www.cenaa.org/data/cms/information-warfare-geopolitical-tool.pdf

${ }^{v}$ Hoffman, F.G., (2007). Conflict in the $21^{\text {st }}$ Century: Rise of Hybrid Wars.

vi Janczewski, L. J., Colarik, A., (2005). Managerial Guide for Handling Cyber-terrorism and Information Warfare.

vii Marsh, A., (2017). The Fear Factor: How One Emotion Connects Altruists, Psychopaths, and Everyone In-Between.

viii Linebarger, P. M. A., (1948). Psychological Warfare.

${ }^{\text {ix }}$ McCombs, M; Reynolds, A (2002). News influence on our pictures of the world. Media effects: Advances in theory and research. 
$3^{\text {rd }}$ International Conference on

SOCIAL SCIENCES IN THE 21ST CENTURY

02-04 JULY, 2021

OXFORD, UNITED KINGDOM

${ }^{x}$ Goffman, E., (1974). An Essay on the Organization of Experience.

${ }^{x i}$ Mohammed, Khaleel, (2015). Does Islamic scripture justify jihad violence? Th San-Diego

Union Tribune, https://www.sandiegouniontribune.com/lifestyle/people/sdut-quran-hadith2015dec19-story.html

xii Urushadze, M. (2020), The Role of Kremlin Propaganda Machine in the "Frame-Games" of International Agenda, Ante Portas Security Studies, No 1(14) DOI: 10.33674/320191, http://anteportas.pl/wp-content/uploads/2020/10/AP.XIV_Urushadze.pdf 